\title{
Prevalence of urinary incontinence and its association with the body mass index (BMI) among pregnant women in Ternate Island
}

\author{
Adi Ariffianto $^{1^{\star}}$, Ova Emilia ${ }^{1}$, Edi Patmini Setya Siswanti ${ }^{1}$, Abdul Wahab $^{2}$ \\ ${ }^{1}$ Department of Obstetry and Gynecology, Faculty of Medicine, Public Health and Nursing/ \\ Dr. Sardjito General Hospital, Universitas Gadjah Mada, Yogyakarta, ${ }^{2}$ Department of \\ Biostatistics, Epidemiology and Population Health, Faculty of Medicine, Public Health and \\ Nursing, Universitas Gadjah Mada, Yogyakarta
}

DOI: http://dx.doi.org/10.19106/JMedScie/005004201811

\section{ABSTRACT}

Urinary incontinence, a condition where a patient cannot withhold urinating, can cause health, social and psychological problems. This condition is not life threatening but can affect their quality of life due to the difficulties of treatment in the psychological and social problems. Even though this disorder is common in pregnancy, the exact cause is still unknown. Many researchers assert that urinary incontinence is due to multifactorial causes. This study aimed to determine the prevalence of urinary incontinence in pregnant women and its relationship with body mass index (BMI). A cross sectional study involving 224 pregnant women in the primary health centers on Ternate Island was conducted using the Questionnaire for Urinary Incontinence Diagnosis (QUID). Respondents with a history of urinary incontinence without pregnancy or positive urinary tract infection diagnosis were excluded from this study. Data were gathered through interviews and physical examinations. The total prevalence of urinary incontinence was $28.6 \%$. Urge incontinence $(39.0 \%)$ was the most common type followed by mixed (37.5\%) and the least common was stress incontinence $(23.4 \%)$. There was a significantly association between urinary incontinence and maternal BMI $(p=0.045)$. Urinary incontinence occured as much as $2.167(95 \% \mathrm{Cl}$ : 1.008 - 4.656) times greater in pregnant women with obesity than those who had an ideal BMI. In conclusion, urge incontinence is the most common type of urinary incontinence. There is a significant correlation between urinary incontinence and the BMI of pregnant women, especially in obese women.

\section{ABSTRAK}

Inkontinensia urin, suatu kondisi ketika seorang pasien yang sulit menahan buang air kecil, dapat menyebabkan masalah kesehatan, social dan psikologi. Kondisi ini tidak bersifat mengancam jiwa tetapi mempengaruhi kualitas hidup pasien karena kesulitan dalam menangani masalah psikologi dan sosial. Meskipun kelainan ini umumnya terjadi pada kehamilan, penyebab sebenarnya masih belum diketahui. Banyak peneliti menyatakan bahwa inkontinensi urin penyebabnya multifaktorial. Penelitian ini bertujuan menetapkan prevalesni inkontinesia urin pada wanita hamil dan hubungannya dengan indeks masa tubuh (IMT). Penelitian ini merupakan penelitian potong lintang yang melibatkan 224 wanita hamil di pusat kesehatan primer di pulau Ternate menggunakan Kuisioner untuk Diagnosis Inkontinensia Urin (KDIU). Responden dengn riwayat inkontinensia urin tanpa kehamilan atau didiagnosis positif infeksi saluran kemih dikeluarkan dalam penelitian ini. Data dikumpulkan melalui wawancara dan pemeriksaan fisik. Prevalensi total inkontinensia urin sebesar $28.6 \%$. Inkontinensia urgensia $(39.0 \%)$ paling banyak terjadi diikuti campuran $(37.5 \%)$ dan paling rendah inkontensia stres $(23.4 \%)$. Ada hubungan 
nyata antara inkontinensia urin dan IMT maternal $(p=0.045)$. Inkontinensia terjadi 2.267 (95\% Cl: $1.008-4.656)$ lebih tinggi pada wanita hamil dengan obesitas daripada dengan mereka dengan IMT ideal. Dapat disimpulkan, inkontinensia urgensi merupakan tipe inkontensia urin paling banyak terjadi. Ada hubungan nyata antara inkontinensi urin dan IMT pada wanita hamil khususnya wanita hamil dengan obesitas.

Keywords: urinary incontinence - BMI - gestational age - pregnancy - obesity

\section{INTRODUCTION}

Health status of pregnant women should be maintained through nutritional aspects, life style and physical activity. This approach is important because it affects their physical and mental condition during pregnancy. Urinary incontinence is one of the conditions that can disturb the quality of life in pregnant women. ${ }^{1,2}$ Previous cohort study in Victoria Australia showed that the prevalence of pregnant women with urinary incontinence is $55.9 \%$. Stress urinary incontinence was the most common type with prevalence $36.9 \%$ followed by mixed $13.1 \%$ and urge type $5.9 \%{ }^{3}$ Unfortunately there is a lack of research about urinary incontinence in Indonesia.

All women can suffer from urinary incontinence in any age that can lead to health, social, and psychological problems for the patient. Urinary incontinence is not life threatening but it can affect their quality of life due to the difficulties in the psychological and social factors treatment. ${ }^{4,5}$ The disorder is related to daily activities, and as a result the sufferer feels less confident, depression, shame, and anxiety. ${ }^{6}$ In Indonesia, nutrition status especially obesitywas stated as a serious condition correlated with overall population health status. $^{7}$

The objective of this study was to determine the prevalence of urinary incontinence in pregnant women, the types of urinary incontinence and the association between urinary incontinence with maternal body mass index (BMI).

\section{MATERIALS AND METHODS}

\section{Population}

An observational study with a cross sectional design was conducted to collect the data about the prevalence of urinary incontinence in pregnant woman using the Questionnaire for Urinary Incontinence Diagnosis (QUID). ${ }^{8,9}$ The target population in this study was pregnant women who lived near the selected health centers in Ternate. The sources of sample population were pregnant women who visited the health centers for antenatal care.

Determination of sample size used a parameter proportion of pregnant women who experienced urinary incontinence, which is $22 \%$ with alpha of 0.05 (confidence level $95 \%$ ) and $90 \%$ power. Estimating a population proportion, the result of the formula calculation of sample size indicates that as many as 66 subjects are required. Taking into account the variations in the area, the number of population in each health center and then considering the design effect of 3 study sites, a total sample of 198 subjects or more is required. Sample selection techniques used in this study included probability sampling with the cluster random sampling method using the primary health care center as the primary sampling unit. By using cluster sampling, in this study we selected six from eight health centers. The number of samples in each cluster depended on the number of pregnant women who visited the health center, and who had previously been invited by the local midwife to come to the clinic on the appointed day to complete the interview and examination of the antenatal care (ANC). The inclusion criteria were pregnant women who come to the health centers and are healthy mentally and physically. The exclusion criteria of this study were pregnant women who experienced urinary tract infections and severe mental disorder. 


\section{Protocol of study}

Weight and height measurements using adult weight and height measuring instruments that are available in the health center. The accuracy of the weight measuring instrument is 0.1 kilograms and $1 \mathrm{~mm}$ for the height measuring instrument. Subject were asked to stand on the scales and then see the results on the measuring scale and note it. Then subjects moved to the height measuring instrument and subjects were asked to stand in an upright position with eyes straight ahead. Examiners then read and noted the results of the height measurement shown on the measuring board. Determining the BMI of pregnant women was different from the normal BMI scale. The following categorizations were based on Rosso and were only used to establish the BMI of pregnant women: underweight $(<19.8)$, eutropic/ideal (19.8 to 26.0), overweight (26.0 to 29.0) and obese $(>29.0) .{ }^{10}$

\section{Statistical analysis}

Descriptive analysis was used to determine the prevalence of pregnancy with urinary incontinence and its relationship with the BMI of the selected pregnant women. Bivariate analyses by Chi-Square and Mantel-Haenzsel techniques were used to find the relationship between risk factors and outcomes. Odds ratio (OR) was used to determine the burden of disease with $95 \%$ confidence interval.

\section{RESULTS}

There are 224 pregnant women respondents who met the inclusion and exclusion criteria. The subjects were distributed among 6 primary health care facilities, namely Siko, Sulamadaha, Kota, Gambesi, Kalumpang, and Kalumata. Each primary health care unit had 37 to 38 subjects who joined this study.

TABLE 1. Characteristics of study subjects

\begin{tabular}{lcc}
\hline Variables & $\mathrm{n}$ & $\%$ \\
\hline Parity & & \\
- Nullipara & 76 & 33.9 \\
- Multipara & 148 & 66.1 \\
Maternal age & & \\
• $\leq 20$ & 27 & 12.0 \\
- $21-30$ & 124 & 55.4 \\
- 31-40 & 69 & 30.8 \\
- > 40 & 4 & 1.8 \\
BMI before pregnancy & & \\
- Underweight & 68 & 30.4 \\
- Ideal & 117 & 52.2 \\
- Overweight & 24 & 10.7 \\
- Obese & 15 & 6.7 \\
BMI during pregnancy & & \\
- Underweight & 23 & 10.3 \\
- Ideal & 123 & 54.9 \\
- Overweight & 41 & 18.3 \\
- Obese & 37 & 16.5 \\
Maternal education & & \\
- Elementary & 20 & 8.9 \\
- Junior HS & 38 & 17.0 \\
- Senior HS & 126 & 56.2 \\
• Diplome & 14 & 6.3 \\
• Bachelor & 26 & 11.6 \\
\hline
\end{tabular}


The median age was 27 years with a range from 16 to 43 . Parity numbers ranged from nullipara $(33.9 \%)$ to multiparous $(66.1 \%)$ with the amount of maximum parity as 6. Education of respondents varied; the levels of the participants were elementary school (8.9\%), junior high school (17.0\%), senior high school (56.2\%), diploma (6.3\%), and bachelor (11.6\%). The BMI before pregnancy for the majority of respondents was in the ideal category, i.e. $52.2 \%$ followed by $30.4 \%$ underweight then $10.7 \%$ overweight and $6.7 \%$ obese. As for BMI of pregnant women during the time of the study measurement, there was a significant increase in pregnant women who had a BMI in the obese category from $6.7 \%$ to $16.5 \%$, overweight changed from $10.7 \%$ to $18.3 \%$ and ideal from $52.2 \%$ to $54.9 \%$. Meanwhile the BMI in the underweight category declined from $30.4 \%$ before pregnancy to $10.3 \%$ during pregnancy.

TABLE 2. Urinary incontinence prevalence

\begin{tabular}{lcc}
\hline Variable & $\mathrm{n}$ & $\%$ \\
\hline Urinary incontinence & & \\
• Yes & 64 & 28.6 \\
• No & 160 & 71.4 \\
Type of urinary inconti- & & \\
nence & & \\
- Stress & 15 & 23.4 \\
- Urge & 25 & 39.0 \\
- Mix & 24 & 37.5 \\
\hline
\end{tabular}

Out of 224 respondents, the pregnant women who experienced urinary incontinence were as many as 64 patients $(28.6 \%)$. The urge incontinence was the most common type of incontinence at $39.0 \%$ of the total who experience urinary incontinence or $11.2 \%$ of the total number of respondents and the mixed type is $37.5 \%$ of total patients with urinary incontinence, or $10.7 \%$ of total respondents. Meanwhile, for the stress incontinence type as much as $23.4 \%$ of total patients experienced this type of urinary incontinence, or $6.7 \%$ of the total respondents.

TABLE 3. Relationship between urinary incontinence and BMI

\begin{tabular}{|c|c|c|c|c|}
\hline \multirow[t]{2}{*}{ BMI } & \multicolumn{2}{|c|}{$\begin{array}{c}\text { Urinary } \\
\text { incontinence }\end{array}$} & \multirow[t]{2}{*}{$\mathrm{p}$} & \multirow[t]{2}{*}{ OR $(95 \% \mathrm{CI})$} \\
\hline & Yes & No & & \\
\hline Ideal & 32 & 91 & & Ref \\
\hline Underweight & 5 & 18 & 0.665 & $0.79(0.271-2.302)$ \\
\hline Overweight & 11 & 30 & 0.918 & $1.04(0.469-2.320)$ \\
\hline Obese & 16 & 21 & 0.045 & $2.17(1.008-4.656)$ \\
\hline
\end{tabular}


The results of data analysis showed the incidence of urinary incontinence occurs as much as 2.167 (95\% CI: 1.008-4.656) more times in pregnant women with obesity compared with pregnant women who have an ideal BMI. These results were statistically significant $(\mathrm{p} \leq 0.05)$. Meanwhile, there was no significant difference in incidence of urinary incontinence between overweight $(\mathrm{OR}=1.043)$ compared to the ideal BMI $(p>0.05)$. The results of the data found that the underweight BMI category had fewer patients experiencing urinary incontinence $(\mathrm{OR}=0.790)$ than the ideal, but it was not statistically significant $(\mathrm{p}>0.05)$.

TABLE 4. Estimate risk from each BMI based on gestational age

\begin{tabular}{clc}
\hline $\begin{array}{c}\text { Gestational } \\
\text { age }\end{array}$ & \multicolumn{1}{c}{ BMI } & OR $(95 \% \mathrm{CI})$ \\
\hline \multirow{3}{*}{$\leq 24$ weeks } & - Ideal & Reference \\
& - Underweight & $0.494(0.127-1.928)$ \\
& - Overweight & $0.674(0.167-2.72)$ \\
& - Obese & $3.088(0.739-12.91)$ \\
\hline \multirow{2}{*}{24 weeks } & - Ideal & Reference \\
& - Underweight & $2.178(0.332-14.277)$ \\
& - Overweight & $1.374(0.502-3.77)$ \\
& - Obese & $2.114(0.814-5.486)$ \\
\hline
\end{tabular}

The data in TABLE 4 indicate that in the gestational age $\leq 24$ weeks, the OR value for underweight compared with the ideal is under 1 and the gestational age of 24 weeks is above 1 . This value means that there is an interaction between the gestational ages towards the relationship between underweight pregnant women compared to the ideal with the occurrence of urinary incontinence. But after examining the OR value for underweight using the Mantel-Haenszel test, which used the ideal as a reference, the OR value was not much different with OR before being stratified meaning the gestational age is not a confounding factor in the relationship. Similar results were obtained in the overweight BMI category compared with the ideal in which the gestational age $\leq$ 24 weeks has OR value below 1 and at the gestational age over 24 weeks above 1 .

Meanwhile a different result was found for comparison of obese with ideal, where the value of OR in gestational age $\leq$ 24 weeks and over 24 weeks was above 1 which means there is no interaction between the gestational age towards the relationship between obese BMI compared with the ideal with the occurrence of urinary incontinence. By doing the analysis of gestational age we found that there is an interaction between gestational age with underweight and overweight BMI compared with the ideal concerning the occurrence of urinary incontinence. The result showed that obese BMI is not affected by gestational age, while the gestational age $\leq 24$ weeks and over 24 weeks compared to the occurrence of urinary incontinence in obese BMI remains high. The results of data analysis also show that pregnancy is not a confounding factor in all categories of BMI towards the occurrence of urinary incontinence.

\section{DISCUSSION}

The definition of urinary incontinence according to the International Continence Society is complaints of uncontrolled urine loss or involuntary urination. ${ }^{11}$ Pregnancy is a risk factor for urinary incontinence. In pregnancy there will be weight gain, changes in collagen, the development of the 
uterus and the fetal weight, and hormonal changes, all of which would cause stress to the pelvic floor muscles and weakening of the strength of the muscles. The weakening of the pelvic floor muscles will cause urinary incontinence. ${ }^{12}$ In this study, the most common type of urinary incontinence is urge incontinence $(39.0 \%)$ followed by mixed $(37.5 \%)$, while the least common type is stress incontinence (23.4\%). These results are in contrast to the studies of Brown et al. ${ }^{3}$ and Sangsawang \& Sangsawang ${ }^{13}$ that show stress incontinence was the most common type of incontinence found in pregnant women and then the second most common type of incontinence was a mixture. Urgency incontinence was a type of incontinence that was not common in pregnant women. This lack of agreement is due to differences in the questionnaires used to diagnose urinary incontinence. This study used the Questionnaire for Urinary Incontinence Diagnosis (QUID) for the diagnosis of urinary incontinence while Brown et al. ${ }^{3}$ was using the baseline questionnaire, so the diagnosis criteria were different and it produced different results. Other differences also appear in the research methods, where this study conducted a cross sectional study with subjects as pregnant women ranging in gestational age 2-40 weeks with a mean of 26 and a mode of 32, while Brown et al. ${ }^{3}$ conducted a cohort design with subject as pregnant women in gestational age $\leq 24$ weeks. Gestational age that was greater when measuring incontinence will affect the results of the diagnosis, since the greater gestational age will increase intra-abdominal pressure so that the occurrence of urinary incontinence is more common. ${ }^{3,13}$

The weight of pregnant women will increase significantly so their BMI will also increase. This condition will increase intra-abdominal pressure on the pelvic floor muscles and urinary bladder. All these conditions will lead to pelvic organ prolapse and increase urethral mobility that causes urinary incontinence. ${ }^{14}$ TABLE 3 shows that obesity is a risk factor of urinary incontinence $(\mathrm{OR}=2.167)$, while underweight is a protective factor compared to ideal BMI $(\mathrm{OR}=0.790)$. There were no differences between overweight compared to ideal BMI towards urinary incontinence incidence $(\mathrm{OR}=1.043)$. These results were statistically significant in obese $(p \leq 0.05)$, but not in underweight and overweight $(p>0.05)$. The results are consistent with other studies where obesity in pregnancy may increase the risk of urinary incontinence and underweight may be a protective factor of the occurrence of urinary incontinence compared with the ideal BMI. ${ }^{3,15-17}$

To support the relationship between BMI and urinary incontinence incidence it is necessary to do stratification of the gestational age. According to a study conducted by Sangsawang \& Sangsawang ${ }^{13}$ in 2013, the greater the gestational age when measuring will influence the diagnosis of urinary incontinence. As discussed above, this condition exists because with greater gestational age there is increase in intraabdominal pressure, so that the occurrence of urinary incontinence is more common. With this proposed theory we stratified gestational age to determine if the gestational age is a confounding factor or influences the outcome of relationship between BMI and the incidence of urinary incontinence. ${ }^{13}$

After analysis by including gestational age as a confounding factor, this study found that in gestational age $\leq 24$ weeks the obese BMI still has the highest risk of the occurrence of urinary incontinence compared with other $\mathrm{BMI}[\mathrm{OR}=3.088 \pm(0.739$ to 12.91$)]$, while underweight is the lowest risk factor [OR = $0.494 \pm(0.127$ to 1.928$)]$. This result is in line with research conducted by Brown et $a l .{ }^{3}$ where in gestational age $\leq 24$ weeks, the obese is also the highest risk factor for the occurrence of urinary incontinence compared to other BMI, but in contrast, the Brown et $a l .^{3}$ study classified the BMI category as the lowest risk factor. Meanwhile in gestational age above 24 weeks, in this study all BMI categories are risk factors for the occurrence of urinary incontinence compared to the ideal, with the highest risk occurring in BMI underweight $[\mathrm{OR}=2.178 \pm(0.332$ to 
14.277)] and obese $[\mathrm{OR}= \pm 2.114(0.814$ to 5.486)]. The Brown et al. ${ }^{3}$ study found that being obese is a risk factor for urinary incontinence compared with the ideal, while being underweight is a protective factor with overweight having the same risk with ideal because it has OR 1.0. This difference occurs because in this research respondents are mostly in the third trimester of gestation or more than 24 weeks and in this research has a mix with one mother having 6 kids, while in the Brown et al. ${ }^{3}$ women are needed to be nulliparous, to have an estimated gestation of $\leq 24$ weeks of pregnancy at enrolment. All aspects considered, it can be concluded that pregnancy is not a confounding factor in the relationship between BMI towards the occurrence of urinary incontinence. ${ }^{3}$

\section{CONCLUSIONS}

The prevalence of urinary incontinence in pregnant women in Ternate is considered high, that is $28.6 \%$ of 224 respondents. The most common type of urinary incontinence is urge incontinence $(39.0 \%)$, followed by mixed $(37.5 \%)$, while the lowest type is stress incontinence $(23.4 \%)$. The results show that there is a relationship between urinary incontinence with BMI of pregnant women in Ternate, where in obese women urinary incontinence occurs 2.617 (95\% CI: 1.008 to 4.656 ) times more as compared to pregnant women with a BMI ideal and this result is statistically significant $(p \leq 0.05)$ with $\mathrm{p}=0.045$. Underweight pregnant women with urinary incontinence occurs less that 0.790 (95\% CI: 0.271 to 2.302$)$ times compared to pregnant women with a BMI of ideal, but the results determined it as not statistically significant $(\mathrm{p}>0.05)$ with $\mathrm{p}=0.665$. Additionally, for overweight BMI there is no significant difference. The study results demonstrate that the gestational age is not a confounding factor in the relationship between body mass index of pregnant women with the occurrence of urinary incontinence.

\section{ACKNOWLEDGEMENTS}

Disclosure statement of any potential of interest for each author; "The authors report no conflict of interest". Financial support of research: The research was supported by the Faculty of Medicine Universitas Gadjah Mada in collaboration with Health Professional Education Quality (HPEQ) Project - Ministry of Education and Culture of Republic of Indonesia.

\section{REFERENCES}

1. Rosevear SK. Handbook of gynaecology management. $1^{\text {st }}$ ed. Great Britain: Blackwell Science, 2002.

2. Hunskaar S, Lose G, Sykes D, Voss S. The prevalence of urinary incontinence in women in four European countries. BRU Int 2014; 93(3):324-30.

3. Brown SJ, Donath S, MacArthur C, McDonald EA, Krastev AH. Urinary incontinence in nulliparous women before and during pregnancy: prevalence, incidence, and associated risk factors. Int Urogynecol J 2010; 21(2):193-202. http://dx.doi.org/10.1007/s00192-009-1011-x

4. López M, Ortiz AP, Vargas R. Prevalence of urinary incontinence and its association with body mass index among women in Puerto Rico. J Women Health 2009; 18(10):1607-14. http://dx.doi.org/10.1089/jwh.2008.1207

5. Staskin D, Hilton $P$, Emmanuel A. Initial Assessment of Incontinence. In: Abrams P, Cardozo L, Khoury S, Wein A editors. Incontinence, vol 1, ed 2005. France: Health Publication Ltd, 2005: 485-517.

6. Prabhu SA, Shanbhag SS. Prevalence and risk factors of urinary incontinence inwomen residing in a tribal area in Maharashtra, India. J Res Health Sci 2013; 13(2):125-30.

7. Hadi H. Gizi lebih sebagai tantangan baru dan implikasinya terhadap kebijakan pembangunan kesehatan nasional. Jurnal Gizi Klinik Indonesia 2004; 1(2):47-53. 
8. Kammerer-doak D \& Abed H. Urinary incontinence. The Female Patient 2007; 32:48-9.

9. Bradley CS, Rahn DD, Nygaard IE, Barber MD, Nager CW, Kenton KS, et al. The Questionnaire for Urinary Incontinence Diagnosis (QUID): validity and responsiveness to change in women undergoing non-surgical therapies for treatment of stress predominant urinary incontinence. Neurourol Urodyn 2010; 29(5):727-34.

http://dx.doi.org/10.1002/nau.20818

10. Wesnes SL, Hunskaar S, Bo K, Rortveit G. Urinary incontinence and weight change during pregnancy and postpartum: a cohort study. Am J Epidemiol 2010; 172(9):1034-44. http://dx.doi.org/10.1093/aje/kwq240

11. Abrams P, Cardozo L, Fall M, Griffiths $\mathrm{D}$, Rosier P, Ulmsten U, et al. The standardisation of terminology in lower urinary tract function: report from the standardisation sub-committee of the International Continence Society. Urology 2003; 61(1):37-49.

12. Santiagu SK, Arianayagam M, Wang A, Rashid P. Urinary incontinence pathophysiology and management outline. Aust Fam Physician 2008; 37(3):106-10.

13. Sangsawang B, Sangsawang N. Stress urinary incontinence in pregnant women: a review of prevalence, pathophysiology, and treatment. Int Urogynecol J 2013; 24(6):901-12. http://dx.doi.org/10.1007/s00192-013-2061-7

14. Hilton P, Dolan LM. Pathophysiology of urinary incontinence and pelvic organ prolapse. BJOG 2004; 111(Suppl 1):5-9.

15. Mishra GD, Hardy R, Cardozo L, Kuh D. Body weight through adult life and risk of urinary incontinence in middle aged women: results from a British prospective cohort. Int $\mathrm{J}$ Obes (Lond) 2012; 32(9): 1415-22. http://dx.doi.org/10.1038/ijo.2008.107

16. Oliveira CD, Seleme M, Cansi PF, Consentino RF, Kumakura FY, Moreira $\mathrm{GA}$, et al. Urinary incontinence in pregnant women and its relation with socio-demographic variables and quality of life. Rev Assoc Méd Bras 2013; 59(5):460-6.

http://dx.doi.org/10.1016/j.ramb.2013.08.002 